\title{
Changes in Physico-Chemical Characteristics of Milk During Dahi Preparation on Fate of Inoculated Bacterial Pathogens
}

\author{
P. Selvan ${ }^{1^{*}}$ and G. Bharath ${ }^{2}$ \\ ${ }^{1}$ Department of Food Safety and Quality Assurance, College of Food and Dairy Technology, \\ TANUVAS, Chennai - 600 052, India \\ ${ }^{2}$ Gopaljee Dairy Foods Private Limited, Unit - 1, Garh Road, Siyana, BulandshaharDistirct, \\ Uttar Pradesh - 245 413, India \\ *Corresponding author
}

\section{A B S T R A C T}

\begin{tabular}{|l|}
\hline K e y w o r d s \\
Dahi, NCDC \\
cultures, pH, \\
Titratable acidity, \\
E. coli AB 1157, \\
Salmonella \\
typhimurium
\end{tabular}

\section{Introduction}

Vast majority of the population in the country and their diverse food habits, cultures, tradition and religions, offer great market for milk and milk products. The consumption pattern of dairy products in the country is primarily skewed towards traditional ones.
Such heritage dairy products are known for their nutritional and functional properties. These products play a significant role in social and religious events as well as considerably contribute to local and national economy. Of the total milk production, 50\% is being consumed by rural households and the rest is sold in the domestic market, wherein $50 \%$ as 
fluid milk, $35 \%$ as traditional products and $15 \%$ as butter, ghee, milk powder and other processed dairy products which includes baby foods, ice cream, whey powder, casein, and milk albumin (Himabindu et al., 2014). Generally, the traditional dairy products has been classified into five major categories viz., Fat rich, Heat and acid coagulated, Heat desiccated, Fermented milk products and Dairy puddings and desserts (Aneja et al., 2002). Fermented milk products also known as culture dairy foods plays a significant role in human nutrition and these products are known to man from time immemorial. Several fermented foods claimed to possess medicinal and nutritional properties. The fermented milk products used in different countries may be broadly classified into three categories which includes i) moderately sour type with pleasant aroma ii) Sour and very high sour types iii) Acid-cum alcohol in addition to lactic acid (Panesar, 2011). At present, the consumer's interest in fermented milk products is gaining momentum. Some of the cultured dairy foods such as bioghurt, yakult, actimel etc., are already marketed as therapeutic and dietetic products. Chhurpi, chhurchirpen, churkham, chhu, philu, Mistidahi etc., are some of the fermented dairy foods of Indian sub-continent and are popular at regional level.

Indian curd, known as Dahi is one of the oldest Indian fermented milk products (Sarkar, 2008) and is consumed by large sections of the population throughout country, either as a part of the daily diet, or as a refreshing beverage (Caballero et al., 2003). Dahi is a semisolid sourish food formed by the process of Lactic acid fermentation. Streptococcus cremoris, $S$. lactis, S. thermophilus, Lactobacillus bulgaricus, L. acidophilus, L. helveticus and Lactobacillus cremorisare some of the microorganisms involved in the preparation of dahi. The product has been prepared, in every household of the country, by back slopping i.e. mixing a small amount of already fermented curd to the boiled and cooled milk. However, changes in lifestyle, increasing number of women entering the workforce and escalation in the disposable income of families led to raise in demand for processed Ready-to-Eat food products including dahi. Consequent technological advances resulted in development of more number of dahi starters and thereby commercialization of dahi. Currently, organized dairies in our country like Mother Dairy, Nestle, Reliance Dairy Life, AmulMasti, Verka, Vita etc., have started production of fermented milk products specially dahi (ananymous, 2012).

In general, during fermentation, the development of essential and safe microflora play a vital role in preventing the outgrowth of spoilage bacteria and food borne pathogens (Tesfaye, 2011). Lactic acid bacteria contribute significantly to fermentation and are attributed to some of their biochemical features. During curdling, they utilize the lactose and other sugars present in milk and produce organic acids such as lactic and or acetic acid. The majority of food-borne biological contaminants, either pathogenic or nonpathogenic, are sensitive to these acids and resulting in low $\mathrm{pH}$. They also produce antibacterial substances such as bacteriocins, hydrogen peroxide, diacetyl., and $\mathrm{CO}_{2}$ which may also play part in the antagonism of LAB on other microorganisms. Although fermented food products are usually considered safe because of the antagonistic effect of LAB, some foodborne pathogens have been reported to survive and grow in fermented milk products (Feresu and Nyathi, 1990). Ashenafi (1992, 1994) indicated the survival of $L$. monocytogenes, Salmonella spp. Staphylococcus aureus and Bacillus cereus for 24-48 h during a preparation of a fermented dairy product. Hence, the safety and wholesomeness of a fermented product may depend on the types of LAB that are involved in the fermentation process (Tesfayeet al., 2011). 
Keeping the above points in view, the present study is proposed to assess the effect of changes in $\mathrm{pH}$ and titratable acidity, brought out by five different commercial dahi starter cultures while dahi making, on fate of inoculated pathogens viz.,Escherichia coli AB1157 and Salmonella typhimurium.

\section{Materials and Methods}

A study to assess the effect of changes in certain physic-chemical characteristics of milk during curding of dahi making on Escherichia coli AB1157 and Salmonella typhimurium was carried out in the Department of Food and Industrial Microbiology, College of Food and Dairy Technology, Chennai during the period between January, 2015 and June, 2015.

\section{Collection of samples}

Cow milk was collected from the cattle farm located at College of Food and Dairy Technology, maintained under Community Cattle Care Centre project. Milk from a single healthy animal that has been selected at random and devoid of antibiotic therapy was collected and utilized throughout the study. The milk was collected immediately after milking in clean polyethyelene terepthalate bottles and transported in insulated, refrigerated containers to laboratory under hygienic conditions.

\section{Chemicals, Media, Buffers and Reagents}

All the chemicals used in the study were of analytical grade, from reputed national and international firms. Dehydrated culture media and broth used were obtained from Hi-media, Mumbai. The recipe for various buffers and reagent used in this study has been listed in appendix.

Test strains

The bacterial strains used in this study are listed in the Table 1. The strains were tested for purity, morphological and biochemical characteristics. All the strains were maintained by sub culturing in the respective broth following manufacture's instruction.

Two standard serotypes viz., Escherichia coli AB1157 (MTCC 1591) and Salmonella typhimurium (MTCC 3231) were reconstituted as per manufacture's instruction and subcultured in nutrient and Rappaport Vassiliadis Salmonella enrichment broth, respectively. Then, sub-cultures were utilized for the inoculation study.

Fivecommercial dahi starter culturesviz.,NCDC91, NCDC154, NCDC159, NCDC161 NCDC 166were separately reconstituted as per manufacture's instruction and sub-cultured in skim milk, Then, subcultures were utilized for the inoculation study.

\section{Inoculation study using Eshcerichia coli AB1157 (MTCC 1591)(Experiment I)}

\section{Sterilization of milk samples}

The milk collected were portioned into $99 \mathrm{ml}$ each and hygienically transferred to six autoclavable containers with screwed cap for each replication. Then, the milk in capped containers was subjected to autoclaving at $121^{\circ} \mathrm{C}$ for $15 \mathrm{~min}$ at $15 \mathrm{psi}$ to kill the inherent microbial flora.

\section{Inoculation of sterilized milk with dahi starter culture}

The sterilized milk in capped container were cooled to room temperature $\left(37^{\circ} \mathrm{C}\right)$ and then, $1 \%$ of each of the five, reconstituted, overnight grown commercial dahi starter cultures were inoculated individually in each of the five containers. Culture maintained by back slopping at students' boarding house has 
been inoculated in the sixth container and kept as control. The initial lactic acid bacterial count in each inoculum has been assessed by spread plate method. All the works has been carried out under aseptic condition in laminar air flow.

\section{Inoculation of Escherichia coli AB1157 (MTCC 1591)}

Each of the starter culture added milk containers were now inoculated separately with Escherichia coli AB1157 (MTCC 1591) at a concentration of approximately 6.60 $\log _{10} \mathrm{CFU} / \mathrm{mlof}$ milk. After inoculation, the containers were kept at $25^{\circ} \mathrm{C}$ for $18 \mathrm{hrs}$ to allow the curdling of milk to occur. All the procedures were carried out aseptically to avoid any contamination.

\section{Microbial analysis}

$18 \mathrm{hrs}$ after incubation at $25^{\circ} \mathrm{C}$, the control and treatment groups were evaluated for Escherichia colicount using spread plate method. Each $5 \mathrm{gm}$ of curd sample was weighed near flame in a sterile stomacher bags and $45 \mathrm{ml}$ of sterile peptone water was added to it. The bag was stomached for $2 \mathrm{~min}$ to get uniform homogenate. Decimal dilutions of homogenate were prepared in sterile peptone water and appropriate serial dilutions were plated in duplicate using spread plate method. All the works was carried out in a clean UV sterilized laminar air flow.

$41.5 \mathrm{~g}$ of Violet Red Bile Agar (VRBA) was suspended in one litre of sterilized distilled water and boiled to dissolve the medium completely. Final $\mathrm{pH}$ was adjusted to $7.4 \pm 0.2$. Approximately $10-15 \mathrm{ml}$ of sterilized media was poured into each sterilized petridishes under aseptic conditions for preparation of plates to inoculate the aliquots. Spread plate method was followed for inoculation of $0.1 \mathrm{ml}$ of aliquots of suitable sample dilutions. Inoculated plates were incubated at $37 \pm 1^{\circ} \mathrm{C}$ for $24 \mathrm{hrs}$. Red to pink colonies of $0.5 \mathrm{~mm}$ in diameter and colonies judged to be borderline cases were counted. The average numbers of colonies were expressed as $\log _{10} \mathrm{CFU} / \mathrm{ml}$ of curd sample

\section{Assessment of Physico-chemical Characteristics \\ pH}

The $\mathrm{pH}$ value of curd samples was determined by a digital $\mathrm{pH}$ meter using the procedure described in AOAC, (2005). Prior to use the $\mathrm{pH}$ meter was standardized with standard buffer solution of $\mathrm{pH} 4$ and 9.2.

\section{Titratable acidity}

Titratable acidity of curd samples were determined using standard procedure. About $10 \mathrm{~g}$ of each curd sample were weighed accurately in suitable dish. Added $30 \mathrm{ml}$ of warm water followed by one $\mathrm{ml}$ of phenolphthalein indicator. Then, the flask has been shaken and titrated against $0.1 \mathrm{~N} \mathrm{NaOH}$ until persistent pink colour developed. Applying similar procedure a blank has been assessed. Then the result was expressed as \% lactic acid by weight $(1 \mathrm{ml} 0.1 \mathrm{NaOH}=$ 0.0090)

$\%$ Titratable acidity $=$

(Titration value of sample - Titration value of blank) X Normality of $\mathrm{NaOH} \mathrm{X} \mathrm{9)}$

Weight of the sample

\section{Inoculation study using Salmonella typhimurium (MTCC 3231)(Experiment II)}

Procedures detailed in Experiment I (sections 3.4.1, 3.4.2, 3.4.3 and 3.4.4) were repeated using Salmonella typhimurium (MTCC 3231) at a concentration of approximately 7.70 $\log _{10} \mathrm{CFU} / \mathrm{ml}$ of milk. Finally, $0.1 \mathrm{ml}$ volumes 
of decimal dilutions were spread in duplicate onto Bismuth Sulphite Agar and incubated at $37^{\circ} \mathrm{C}$ for $24 \mathrm{hrs}$. The typical colonies were counted and expressed as $\log _{10} \mathrm{cfu} / \mathrm{g}$ of sample.

Similarly, procedures described in 2.4.5.1 and 2.4.5.2 has been repeated in this experiment to assess the $\mathrm{pH}$ and Titratable acidity.

\section{Statistical analysis}

Data collected from each experiment was analyzed using standard statistical procedures (Snedecor and Cochran, 1994). Analysis of variance (ANOVA) procedure used to determine the significant difference $(p<0.05)$ among means obtained for different treatments. The interacting effect of $\mathrm{pH}$ and Titratable acidity on counts of inoculated pathogens were assessed by Two-way analysis of variance.

\section{Results and Discussion}

A study to assess the effect of $\mathrm{pH}$ and titratable acidity on inoculated pathogens viz., Eshcerichia coli AB1157 and Salmonella typhimurium was carried out. The results were statistically analyzed and presented along with analysis of variance and correlation in Table 2, $2 \mathrm{a}, 2 \mathrm{~b}, 3,3 \mathrm{a}$ and $3 \mathrm{~b}$.

\section{Experiment I}

\section{pH}

The mean \pm S.E values and analysis of variance for $\mathrm{pH}$ of control and treatment groups are presented in Table 2 .

Overall mean $\mathrm{pH}$ value of dahi ranged between 4.40 and 5.20 where control group had shown significantly lower $(\mathrm{p} \leq 0.05) \mathrm{pH}$ values compared to other treatment groups except T3. Among the treatment groups, though $\mathrm{T} 3$ recorded significantly lower $\mathrm{pH}$ values $(p \leq 0.05)$ no significant difference was observed in mean $\mathrm{pH}$ values of $\mathrm{T} 3, \mathrm{~T} 2, \mathrm{~T} 1$ and $\mathrm{T} 4$, respectively.

\section{Titratable acidity}

The mean \pm S.E values and analysis of variance for Titratable acidity of control and treatment groups are presented in Table 2.

Overall mean titratable acidity value of dahi ranged between 0.35 and 1.00 (expressed in \% of lactic acid) where control group had shown significantly higher $(\mathrm{p} \leq 0.05)$ titratable acidity compared to treatment groups. Among the treatment groups, T3 recorded significantly higher titratable acidity values $(\mathrm{p} \leq 0.05)$ whereas no significant difference was observed in the mean titratable acidity of $\mathrm{T} 1$, $\mathrm{T} 2$, $\mathrm{T} 4$ and $\mathrm{T} 5$.

\section{E.col iAB1157 (MTCC 1591) count}

The mean \pm S.E values and analysis of variance for Eshcerichia coli AB1157 count of control and treatment groups are presented in Table 2.

Overall mean E. coli Count of dahi ranged between 4.18 and 7.75 ( $\log _{10} \mathrm{cfu} / \mathrm{g}$ of sample) where control group had shown significantly lower $(\mathrm{p} \leq 0.05)$ E.coli Count compared to treatment groups. Among the treatment groups, T1 recorded significantly lower $E$. coli count $(\mathrm{p} \leq 0.05)$ and however, did not differ significantly from that of T4. The mean E.coli Count of T2, T3 and T5 did not differ significantly.

\section{Experiment II}

pH

The mean \pm S.E values and analysis of variance for $\mathrm{pH}$ of control and treatment groups are presented in Table 2. 
Overall mean $\mathrm{pH}$ value of dahi ranged between 4.45 and 5.32 where control group had shown significantly lower $(\mathrm{p} \leq 0.05) \mathrm{pH}$ values compared to treatment groups. Among the treatment groups, T3 recorded significantly lower $\mathrm{pH}$ values $(\mathrm{p} \leq 0.05)$ followed by $\mathrm{T} 4$ whereas no significant difference was observed in mean $\mathrm{pH}$ values of $\mathrm{T} 1, \mathrm{~T} 2$ and $\mathrm{T} 5$, respectively.

\section{Titratable acidity}

The mean \pm S.E values and analysis of variance for Titratable acidity of control and treatment groups are presented in Table 2 .

Overall mean titratable acidity value of dahi ranged between 0.34 and 0.94 (expressed in $\%$ of lactic acid) where control group had shown significantly higher $(\mathrm{p} \leq 0.05)$ titratable acidity compared to treatment groups. Among the treatment groups, T3 recorded significantly higher titratable acidity values $(p \leq 0.05)$. However, mean titratable acidity of T3, T1 and T4 did not differ significantly.

\section{S.typhimurium count}

The mean \pm S.E values and analysis of variance for S.Typhimurium Countof control and treatment groups are presented in Table 2. Overall mean S.Typhimurium Count of dahi ranged between 8.43 and $9.61\left(\log _{10} \mathrm{cfu} / \mathrm{g}\right.$ of sample) where control group had shown significantly lower $(\mathrm{p} \leq 0.05)$ S.Typhimurium Count compared to treatment groups. Among the treatment groups, T4 recorded significantly lower count $(\mathrm{p} \leq 0.05)$. However, mean S.Typhimurium Count of T4, T5 and T3 did not differ significantly.

Table.1 Bacterial strains used for study

\begin{tabular}{|c|l|c|}
\hline S.No & Bacterial Strain & Reference No. \\
\hline $\mathbf{1 .}$ & Escherichia coli AB1157 & MTCC 1591 \\
\hline 2. & Salmonella typhimurium & MTCC 3231 \\
\hline 3. & Dairy Starter & NCDC91 \\
\hline $\mathbf{4 .}$ & Dairy Starter & NCDC154 \\
\hline 5. & Dairy Starter & NCDC159 \\
\hline 6. & Dairy Starter & NCDC161 \\
\hline 7 & Dairy Starter & NCDC166 \\
\hline
\end{tabular}

Table.2 Mean \pm SE values of pH, Titratable acidity and Eshcerichia coli AB1157 (MTCC 1591) count in Dahi (Experiment I)

\begin{tabular}{|c|c|c|c|}
\hline Treatment groups & $\mathrm{pH}$ & $\begin{array}{c}\text { Titratable Acicity } \\
\text { (as \% of Lactic acid) }\end{array}$ & $\begin{array}{c}\text { Eshcerichia coli AB 1157 } \\
\text { count }\end{array}$ \\
\hline Control (BS*) & $4.40 \pm 0.01^{\mathrm{c}}$ & $1.00 \pm 0.04^{\mathrm{a}}$ & $4.18 \pm 0.20^{\mathrm{c}}$ \\
\hline $\mathrm{T} 1(\mathrm{NCDC154})$ & $4.80 \pm 0.01^{\mathrm{ab}}$ & $0.46 \pm 0.08^{\mathrm{c}}$ & $6.26 \pm 0.13^{\mathrm{b}}$ \\
\hline T2 (NCDC161) & $4.96 \pm 0.02^{\mathrm{ab}}$ & $0.35 \pm 0.06^{\mathrm{c}}$ & $7.65 \pm 0.09^{\mathrm{a}}$ \\
\hline T3 (NCDC166) & $4.76 \pm 0.02^{\mathrm{bc}}$ & $0.65 \pm 0.05^{\mathrm{b}}$ & $7.41 \pm 0.32^{\mathrm{a}}$ \\
\hline T4 (NCDC159) & $5.16 \pm 0.02^{\mathrm{ab}}$ & $0.45 \pm 0.06^{\mathrm{c}}$ & $6.39 \pm 0.07^{\mathrm{b}}$ \\
\hline T5 $(\mathrm{NCDC} 1)$ & $5.20 \pm 0.32^{\mathrm{a}}$ & $0.41 \pm 0.06^{\mathrm{c}}$ & $7.75 \pm 0.18^{\mathrm{a}}$ \\
\hline
\end{tabular}

*Back slopping

Mean bearing different superscript in a column differ significantly $(\mathrm{p} \leq 0.05)$ 
Table.2a ANOVA for Inoculation study using Eshcerichia coli AB1157 (MTCC 1591) (Experiment I)

\begin{tabular}{|c|c|c|c|c|c|c|}
\hline & & Sum of Squares & df & Mean Square & $\mathbf{F}$ & Sig. \\
\hline \multirow[t]{3}{*}{ pH } & Between Groups & 2.619 & 5.00 & .524 & 5.02 & .002 \\
\hline & Within Groups & 3.133 & 30.00 & .104 & & \\
\hline & Total & 5.752 & 35.00 & & & \\
\hline \multirow[t]{3}{*}{ TA } & Between Groups & 1.707 & 5.00 & .341 & 15.96 & .000 \\
\hline & Within Groups & .642 & 30.00 & .021 & & \\
\hline & Total & 2.348 & 35.00 & & & \\
\hline \multirow[t]{3}{*}{ ECC } & Between Groups & 54.712 & 5.00 & 10.942 & 52.99 & .000 \\
\hline & Within Groups & 6.195 & 30.00 & .207 & & \\
\hline & Total & 60.907 & 35.00 & & & \\
\hline
\end{tabular}

Table.2b Correlations between pH, Titratable Acidity and Eshcerichia coli AB1157 count (Experiment I)

\begin{tabular}{|c|c|c|c|c|}
\hline & & pH & $\mathbf{T A}$ & ECC \\
\hline \multirow[t]{3}{*}{ pH } & Pearson Correlation & 1 & $-.458^{* *}$ & $.510^{* *}$ \\
\hline & Sig. (2-tailed) & & 0.00 & .001 \\
\hline & $\mathrm{N}$ & 36 & 36.00 & 36 \\
\hline \multirow[t]{3}{*}{ TA } & Pearson Correlation & $-.458^{* *}$ & 1.00 & $-.698^{* *}$ \\
\hline & Sig. (2-tailed) & .005 & & .000 \\
\hline & $\mathrm{N}$ & 36 & 36.00 & 36 \\
\hline \multirow[t]{3}{*}{$\mathbf{E C C}$} & Pearson Correlation & $.510^{* *}$ & $-.698^{* *}$ & 1 \\
\hline & Sig. (2-tailed) & .001 & 0.00 & \\
\hline & $\mathrm{N}$ & 36 & 36.00 & 36 \\
\hline
\end{tabular}

Table.3 Mean \pm SE values of $\mathrm{pH}$, Titratable acidity and Salmonella typhimurium (MTCC 3231) count in Dahi (Experiment II)

\begin{tabular}{|c|c|c|c|}
\hline Treatment groups & pH & $\begin{array}{c}\text { Titratable Acicity } \\
\text { (as \% of Lactic acid) }\end{array}$ & S.Typhimurium Count \\
\hline Control (BS*) & $4.45 \pm 0.01^{\mathrm{a}}$ & $0.94 \pm 0.05^{\mathrm{a}}$ & $8.43 \pm 0.11^{\mathrm{c}}$ \\
\hline T1 $(\mathbf{N C D C 1 5 4})$ & $5.32 \pm 0.02^{\mathrm{d}}$ & $0.40 \pm 0.05^{\mathrm{bc}}$ & $9.61 \pm 0.06^{\mathrm{a}}$ \\
\hline T2 (NCDC161) & $5.29 \pm 0.01^{\mathrm{d}}$ & $0.35 \pm 0.02^{\mathrm{c}}$ & $9.60 \pm 0.10^{\mathrm{a}}$ \\
\hline T3 (NCDC166) & $4.97 \pm 0.02^{\mathrm{c}}$ & $0.50 \pm 0.03^{\mathrm{b}}$ & $9.41 \pm 0.05^{\mathrm{ab}}$ \\
\hline T4 (NCDC159) & $4.89 \pm 0.02^{\mathrm{b}}$ & $0.46 \pm 0.08^{\mathrm{bc}}$ & $9.22 \pm 0.14^{\mathrm{b}}$ \\
\hline T5(NCDC91) & $5.30 \pm 0.01^{\mathrm{d}}$ & $0.34 \pm 0.05^{\mathrm{c}}$ & $9.38 \pm 0.06^{\mathrm{ab}}$ \\
\hline
\end{tabular}

*Back slopping

Mean bearing different superscript in a column differ significantly $(\mathrm{p} \leq 0.05)$ 
Table.3a ANOVA for Inoculation study using Salmonella typhimurium (MTCC 3231) (Experiment II)

\begin{tabular}{|l|l|c|c|c|c|c|}
\hline $\mathbf{p H}$ & $\begin{array}{c}\text { Sum of } \\
\text { Squares }\end{array}$ & $\mathbf{d f}$ & $\begin{array}{c}\text { Mean } \\
\text { Square }\end{array}$ & F & Sig. \\
\hline & $\begin{array}{l}\text { Between } \\
\text { Groups }\end{array}$ & 3.520 & 5 & .704 & 451.916 & .000 \\
\hline Within Groups & .047 & 30 & .002 & & \\
\hline Total & 3.567 & 35 & & & \\
\hline TA & Between & 1.510 & 5 & .302 & 22.767 & .000 \\
\hline & Groups & & & & & \\
\hline Within Groups & .398 & 30 & .013 & & \\
\hline S.Typhimurium \\
count & Total & 1.908 & 35 & & & \\
& $\begin{array}{l}\text { Between } \\
\text { Groups }\end{array}$ & 5.794 & 5 & 1.159 & 22.816 & .000 \\
& Within Groups & 1.524 & 30 & .051 & & \\
\hline & Total & 7.317 & 35 & & & \\
\hline
\end{tabular}

Table.3b Correlations between $\mathrm{pH}$, Titratable Acidity and S.Typhimurium count (Experiment II)

\begin{tabular}{|c|c|c|c|c|}
\hline \multirow{4}{*}{ pH } & & pH & TA & STC \\
\hline & Pearson Correlation & 1 & $-.829^{* *}$ & $.825^{* * *}$ \\
\hline & Sig. (2-tailed) & & .000 & .000 \\
\hline & $\mathrm{N}$ & 36 & 36 & 36 \\
\hline \multirow[t]{3}{*}{ TA } & Pearson Correlation & $-.829^{* *}$ & 1 & -.858 ** \\
\hline & Sig. (2-tailed) & .000 & & .000 \\
\hline & $\mathrm{N}$ & 36 & 36 & 36 \\
\hline \multirow{3}{*}{ STC } & Pearson Correlation & $.825^{* *}$ & $-.858^{* *}$ & 1 \\
\hline & Sig. (2-tailed) & .000 & .000 & \\
\hline & $\mathrm{N}$ & 36 & 36 & 36 \\
\hline
\end{tabular}

\section{Correlation Studies (Experiment I and II)}

Pearson correlation studies for experiment I revealed the existence of low to medium positive correlation between $\mathrm{pH}$ and E.coli count and low to medium negative correlation between the Titratable acidity and E.coli count.

Similarly, in experiment II, high positive and negative correlation was observed between $\mathrm{pH}$ as well as titratable acidity and Salmonella typhimurium count, respectively.
pH, Titratable acidity, E. coli $A B 1157$ and Salmonella typhimurium counts (Experiment I and II)

The common occurrence of different species of bacteria in milk raises a question as to their significance in organoleptic spoilage or public health. The organisms mostly found in milk and milk products generally originate either as endogenous flora i.e. from the animal or added during collection and processing as exogenous contaminants. 
E.coli and Salmonella typhimurium are such common contaminants in milk and hence, this inoculation study has been conducted to assess the effect of $\mathrm{pH}$ and developing titratable acidity on the fate of such opportunistic pathogens while curdling of milk during curd preparation.

$\mathrm{pH}$ value of dahi, in experiment I and II, ranged between 4.45 and 5.32 and 4.45 and 5.32 , respectively where control group had shown significantly lower $(\mathrm{p} \leq 0.05) \quad \mathrm{pH}$ values. The results of the study is in concordance with the results of Chanda et al., (2013) who assessed the $\mathrm{pH}$ values of curd samples sold in different regions of Bangladesh. Samantaet al.(2015) also observed similar $\mathrm{pH}$ values in commercially available curd samples.

Titratable acidity values (expressed as \% of Lactic acid), in experiment I and II, ranged between 0.35 and 1.00 and 0.34 and 0.94 , respectively. Sarkar et al.(2012) also obtained higher titratable acidity (between 0.92 and 1.11) values while assessing curd samples. However, the lower titratable acidity obtained in this study might be attributed to lower number of cells in initial inoculum and thereby lower quantum of weak acids in curd or presence of increased amount of buffering substances in the milk.

In experiment I, the milk samples were inoculated with Eshcerichia coli AB1157 (MTCC 1591) approximately at the concentration of $6.70 \log _{10} \mathrm{cfu} / \mathrm{ml}$ of sample. Upon incubation for a period of $18 \mathrm{hrs}$, the mean E. coli count had ranged between 4.18 and 7.75 ( $\log _{10} \mathrm{cfu} / \mathrm{g}$ of sample) where control group had shown significantly lower $(\mathrm{p} \leq 0.05)$ E.coli Count compared to treatment groups. Interestingly, in control group the initial $E$. coli count was reduced by $2.52 \log _{10} \mathrm{cfu} / \mathrm{g}$ of milk. Similarly, treatment groups T1 and T4 recorded reduction in initial count by 0.44 and
$0.31 \log _{10} \mathrm{cfu} / \mathrm{g}$ of samples, respectively. Conversely, other treatment groups observed significant growth in initial inoculums level. The reduction observed in control and some of the treatment groups could be attributed to their $\mathrm{pH}$ and titratable acidity values. The control dahi sample has been prepared by back slopping technique and hence, would have contained mixed population of dahi starters that might be reason appreciable increase in titratable acidity and lower $\mathrm{pH}$. The latter events would have resulted in highly significant reduction in $E$. coli count.

In experiment II, the milk samples were inoculated with Salmonella typhimurium (MTCC 3231)approximately at the concentration of $7.70 \log _{10} \mathrm{cfu} / \mathrm{ml}$ of sample. Upon incubation for $18 \mathrm{hrs}$, the mean Salmonella typhimurium (MTCC 3231) countranged between 8.43 and 9.61 $\left(\log _{10} \mathrm{cfu} / \mathrm{g}\right.$ of sample) where control group had shown significantly lower $(\mathrm{p} \leq 0.05)$ Salmonella typhimuriumCount compared to treatment groups. However, the initial Salmonella typhimurium count did not reduced but increased in control and treatment groups studied. However, this increase in the Salmonella typhimuriumcount was significantly lower $(\mathrm{p} \leq 0.05)$ in control when compared to treatment groups. This indicates that the developing acidity and reduction in $\mathrm{pH}$ had little effect on S. typhymurium growth but was not able to reduce the number of organisms. This might be due to the acid adaptation of the $S$. typhymurium strain that has been utilized in the inoculation study.

\section{References}

Aneja, R.P., Mathur, B.N., Chandan, R.C. and Banerjee, A.K..(2002). Technology of Indian dairy products. A Dairy India Publication.122-125.

Ashenafi, M. 1992. Growth potential of and inhibition of Bacillus cereus and 
Staphylococcus aureus during the souring of Ergo. A traditional Ethiopian fermented milk. Ethiopian Journal of Health Development. 6: 23-30.

Ashenafi, M. 1994. The aerobic microflora and lactic acid bacteria of market Ayib. Ethiopian Journal of Agricultural Sciences. 14: 104-111.

Association of Official Analytical Chemists, 2005. Official Methods of Analysis of the Association of Analytical Chemists International, 18th ed.

Caballero, B., P. Finglas and L. Trugo, 2003.Encyclopaedia of Food Sciences and Nutrition. 2 ndEdn., Academic Press, UK., pp: 75-94.

Chanda, G.C., Islam, M.R. Ghosh, K.K. and Deb, A.2013. Study on Chemical and Microbiological quality of BograDahi in Bangladesh. YYU Veteriner Fakultesi Dergisi, 2013, 24 (3), 129 - 132

Feresu S.B. andNyathi H. 1990. Fate of pathogenic and non-pathogenic Escherichia coli strains in two fermented milk products. Journal of Applied Bacteriology. 69: 814-821.

Himabindu, T., Subrahmanyam S.E.V., Bhat, M. S. (2014). Swot analysis of dairy industry in India. International Journal of Scientific Research, 3(1): 2277 8179.

Panesar, P. (2011) "Fermented Dairy
Products: Starter Cultures and Potential Nutritional Benefits," Food and Nutrition Sciences, Vol. 2 No. 1, pp. 4751.

Samanta, A, Pradhan, S., Mandal, A., Patra, A., Roy, S., Mandal, S., Kar, S., Sinha, B and Nandi, D.K, 2015.Effect of starter culture on development of curd (dahi) and their antagonistic property against some enteric pathogen.2(1):3039. Indian J Microbiol Res., 2(1):30-39.

Sarkar, S. (2008). Innovations in Indian Fermented Milk Products - A Review. Food Biotechnol. 22. 78-97.

Sarkar M.M., Nahar, T.N.,Alam, M.K., Rahman, M.M., Rashid, M.H. and Islam, M.A. 2012. Chemical and bacteriological quality of popular Dahi available in some selected areas of Bangladesh. Bang. J. Anim. Sci. 2012. 41 (1): 47-51

Snedecor, G.W. and Cochran, W.G. (1994).Statistical methods, The Iowa State University Press, Iowa.

Tesfaye, A., Mehari, T., and Ashenafi, M. (2011). Inhibition of some foodborne pathogens by pure and mixed LAB cultures during fermentation and storage of ergo, a traditional Ethiopian fermented milk. ARPN Journal of Agricultural and Biological Science. 6.

\section{How to cite this article:}

Selvan, P. and Bharath, G. 2018. Changes in Physico-Chemical Characteristics of Milk During Dahi Preparation on Fate of Inoculated Bacterial Pathogens. Int.J.Curr.Microbiol.App.Sci. 7(12): 2884-2893. doi: https://doi.org/10.20546/ijcmas.2018.712.328 